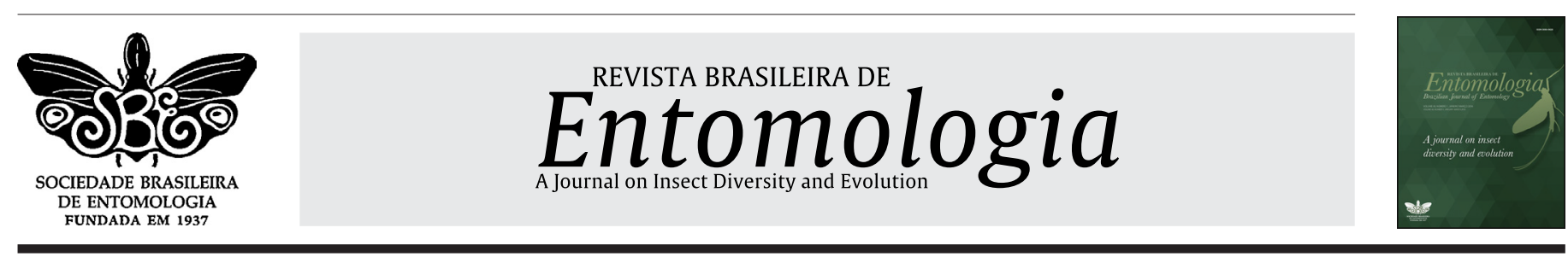

\title{
Effect of soil class and moisture on the depth of pupation and pupal viability of Bactrocera carambolae Drew \& Hancock (1994)
}

\author{
Eric Joel Ferreira do Amaral', Maria do Socorro Miranda de Sousa', \\ Jhulie Emille Veloso dos Santos², Lauane Monteiro Costa ${ }^{3}$, \\ Nagib Jorge Melém Júnior ${ }^{4}$, José Julio de Toledo', Ricardo Adaime ${ }^{4 *}$ \\ ${ }^{1}$ Universidade Federal do Amapá, Programa de Pós-graduação em Biodiversidade Tropical, Macapá, AP, Brasil. \\ ${ }^{2}$ Faculdade de Macapá (FAMA), Macapá, AP, Brasil. \\ ${ }^{3}$ Universidade Federal do Amapá, Curso de Ciências Ambientais, Macapá, AP, Brasil. \\ ${ }^{4}$ Empraba Amapá, Macapá, AP, Brasil.
}

\section{A R T I C L E I N F O}

\section{Article history:}

Received 07 August 2020

Accepted 23 December 2020

Available online 22 February 2021

Associate Editor: Gustavo Graciolli

\section{Keywords:}

Biology

Carambola fruit fly

Fruit flies

Textural classes

\begin{abstract}
A B S T R A C T
Bactrocera carambolae is a quarantine pest present in Brazil and today represents the main phytosanitary barrier to the export of the fresh fruits produced in the country. The effect of soil classes and moisture on the pupation depth and pupal viability of this insect was evaluated. Soils with three textural classes (sandy, sandy clay loam and clay loam) and four moisture levels ( $0 \%, 30 \%, 60 \%$ and $90 \%$ of field capacity of each soil) were used, for a total of 12 treatments with six repetitions. The pupation depths varied from the surface to $5 \mathrm{~cm}$. The soil class was the most significant variable regarding the pupal development of $B$. carambolae. The moisture level did not have a significant effect on the pupation depth or pupal emergence, but there was a strong effect of the interaction of soil texture and moisture on the pupal viability, with an increase in emergence with higher moisture in the clay loam and sandy clay loam soils.
\end{abstract}

\section{Introduction}

The carambola fruit fly, Bactrocera carambolae Drew \& Hancock (Diptera: Tephritidae), is considered a quarantine pest in Brazil due to its economic importance. Its presence is currently restricted to the states of Amapá, Pará and Roraima, where it is a target for control efforts by the Ministry of Agriculture, Animal Husbandry and Supply (MAPA, 2018). Its occurrence is considered to be the main phytosanitary barrier to the export of fresh fruits produced in Brazil, since its presence in productive areas is cause for quarantine restrictions imposed by importing countries (Godoy et al., 2011). The dispersion of the carambola fruit fly to other fruit producing regions of Brazil could generate losses estimated at USD 34 million in the first three years, only considering national production of mangoes (Miranda et al., 2015).

Bactrocera carambolae infests more than 100 species of fruiting plants in Southeast Asia, its center of origin (Malavasi, 2015). In Brazil, the full list of hosts contains 26 plant species belonging to nine botanical families (Adaime et al., 2016; Belo et al., 2020). During the

\footnotetext{
* Corresponding author.

E-mail: ricardo.adaime@embrapa.br (R. Adaime).
}

free-living stage, females lay their eggs directly on the fruit where the larvae develop. At the end of the larval stage, larvae leave the fruit and migrate to the soil where they pupate. Adult emergence takes place between eight and 11 days later (Malavasi, 2015; Castilho et al., 2019).

Although pupal survival still largely depends on larval development, when the organism accumulates and stores reserve substances (Malavasi and Zucchi, 2000), pupae are exposed to several factors that can affect their survival during the period they spend in the soil (Salles et al., 1995; Hulthen and Clarke, 2006).

The soil is a system composed of minerals with pores occupied by water and air, together with an organic part, composed basically of three phases (solid, liquid, gas). The complex interaction of these variables determines the quality of the substrate for the development of plants and animals (Buckman and Brady, 1974). According to Nikiforoff (1941), the association of the soil constituents in aggregated particles defines the structure of the soil, with differences in size (from microscopic to macroscopic), form, stability and degree of particle separation. According to the size of the aggregated particles, the soil structure is divided into 
two categories: microstructure when smaller than $1 \mathrm{~mm}$ in diameter; and macrostructure when larger than $1 \mathrm{~mm}$.

The structure and complexity of the soil have a significant effect on the living organisms (microscopic and macroscopic plants and animals) that live in or depend on it, either directly or indirectly. Characteristics such as composition and size of the particles interact with the presence of water and air, and as a consequence affect the activity of the microbes and other organisms that depend on the soil. The natural supply of water in the soil occurs by infiltration or runoff from rainfall (Moniz, 1975). To understand the relations of the watersoil-plant system, over the years many studies have been conducted that have established "constants" to classify soil moisture. Among these is field capacity, which is defined as the saturation point, the amount of moisture or water content held in the soil after excess water has drained away and the rate of downward movement has materially decreased (Veihmeyer and Hendrickson, 1931, 1949; Moniz, 1975). Soil moisture is related with the survival of insects by affecting the availability of oxygen, because moisture limits the soil aeration by filling the pores. Although the most sensitive development stage of $B$. carambolae occurs in the soil, no information is available about the effect of soil structure, type and moisture level on the survival of the immature stages of the species.

Studies conducted with other species of Tephritidae have found that the soil class and moisture level influence the pupal development and mortality. For example, soils with large particles generally have a structure with ample open pores, which facilitates the larval movement and penetration to greater depths (Hennessey, 1994; Dimou et al., 2003). Eskafi and Fernandez (1990) and Alyokhin et al. (2001) suggested that the larvae of tephritids preferably pupate in moist soils with large particle sizes. In particular, Alyokhin et al. (2001) reported that the majority of larvae of Bactrocera dorsalis (Hendel) pupate in shaded areas to avoid desiccation. According to Jackson et al. (1998), excessive water loss during pupation is an important cause of mortality of $B$. dorsalis and Ceratitis capitata(Wiedemann). Hulthen and Clarke (2006) observed that factors such as moisture level and soil type have a significant interaction regarding the mortality of the pupae of Bactrocera tryoni (Froggatt).

Since $B$. carambolae remains in the soil during its most vulnerable life stage, it is essential to study the soil variables that affect the species. However, to the best of our knowledge, there is no basic information on the effects of soil particle size and moisture level on the species' reproductive success. This knowledge is important to understand the distribution potential of this species in Brazil, especially in the fruitproducing areas that serve as hosts for the carambola fruit fly. Also, it can be useful for development of sampling methods, and especially for strategies to manage this pest. For example, a promising control strategy is the application of the entomopathogenic fungus Metarhizium anisopliae in the soil surface, in the projection of the crown of fruit plants. Recent work has indicated that a fungus strain obtained in the Brazilian Amazon causes significant mortality of larvae and pupae of B. carambolae(Silva et al., 2016; Brito et al., 2019). Hence, the aim of this work was to evaluate the effects of different soil classes and moisture levels on the pupal development of $B$. carambolae.

\section{Materials and methods}

\section{Study location}

The study was conducted at the Plant Protection Laboratory of Embrapa Amapá (000’48.7”S, 5104'59.9”W), in Macapá, Amapá, in northern Brazil, in a room with controlled conditions of temperature $\left(26 \pm 0.5^{\circ} \mathrm{C}\right)$, relative humidity $(60 \pm 10 \%)$ and photoperiod $(12: 12 \mathrm{~h})$.

\section{Source of the insects}

Third-instar larvae of $B$. carambolae were obtained from a colony maintained since 2013 in the Plant Protection Laboratory, according to the methodology adapted from Bariani et al. (2016), using a diet for larvae based on carrots. The diet consisted of 500 grams of raw peeled carrots, $500 \mathrm{~g}$ of cooked peeled carrots, $500 \mathrm{~g}$ of sugar, $600 \mathrm{~g}$ of cornmeal, $100 \mathrm{~g}$ of brewer's yeast, $14.4 \mathrm{~g}$ of critic acid, $4.4 \mathrm{~g}$ of sodium benzoate, $4.4 \mathrm{~g}$ of methylparaben, $100 \mathrm{ml}$ of water to dilute the citric acid and $100 \mathrm{ml}$ to dilute the sodium benzoate, and 70\% alcohol to dilute the methylparaben. The ingredients were processed in a grinder and homogenized in a blender and then stored in trays in a freezer.

We provided three artificial oviposition containers (Fig. 1A), consisting of plastic vials of $80 \mathrm{ml}$, perforated with a pin, containing a piece of guava to stimulate oviposition and distilled water to keep the eggs from drying out. The containers were maintained in a cage for rearing B. carambolae of the seventh generation for $24 \mathrm{~h}$ (Fig. 1B). After this period, the eggs were collected, placed on filter paper (Fig. 1C) and kept in plastic trays containing the feed (Fig. 1D) inside paper envelopes (Fig. 1E), which were placed in a BOD incubator. The trays were monitored for approximately nine days, until obtaining thirdinstar larvae, the stage nearest the moment of pupation.

\section{Characteristics of the soils tested}

We selected soils that are representative of commercially cultivated areas in the state of Amapá, in the classes sandy, sandy clay loam and clay loam, collected respectively in the districts of Nova Colina

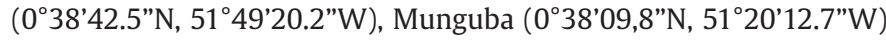
and Matapi ( $\left.0^{\circ} 38^{\prime} 09.8^{\prime \prime} \mathrm{N}, 51^{\circ} 20^{\prime} 12.7^{\prime \prime} \mathrm{W}\right)$, in the municipality of Porto Grande, Amapá.

Deformed samples weighing $8 \mathrm{~kg}$ were collected from the topmost layer (to a depth of $20 \mathrm{~cm}$ ) of each soil class. The samples were taken to the Soil Laboratory of Embrapa Amapá in the city of Macapá, where they were analyzed regarding granulometry to determine texture, according to Teixeira et al. (2017). The samples were sifted (2 mm mesh) and dried in the shade for $48 \mathrm{~h}$ (Table 1 ).

\section{Experimental protocol}

The material used and experimental procedures were the same as those developed and described by Amaral et al. (2019), summarized below. Three soil texture classes were tested (sandy, sandy clay loam and clay loam) and four soil moisture levels (0\%,30\%,60\% and 90\%) (Fig. 2A), for a total of 12 treatments with 6 repetitions. Cylindrical polystyrene foam containers were used $(7 \mathrm{~cm}$ diameter $\mathrm{x} 10 \mathrm{~cm}$ height), divided into $1 \mathrm{~cm}$ rings, which were stacked (Fig. 2B). Each container received 20 third-instar larvae of $B$. carambolae on the soil surface, for a total of 1,440 larvae.

Table 1

Granulometric analysis of the soil samples.

\begin{tabular}{lccc}
\hline \multicolumn{1}{c}{ Texture classification } & Sandy & Sandy clay loam & Clay loam \\
\hline $\begin{array}{l}\text { Clay } \\
(<0.002 \mathrm{~mm}) \mathrm{g} / \mathrm{kg}\end{array}$ & 64 & 325 & 289 \\
$\begin{array}{l}\text { Coarse sand } \\
(0.2 \text { to } 2 \mathrm{~mm}) \mathrm{g} / \mathrm{kg}\end{array}$ & 660 & 330 & 215 \\
$\begin{array}{l}\text { Fine sand } \\
(0.05 \text { to } 0.2 \mathrm{~mm}) \mathrm{g} / \mathrm{kg}\end{array}$ & 220 & 260 & 150 \\
$\begin{array}{l}\text { Silt } \\
(0.002 \text { to } 0.5 \mathrm{~mm}) \mathrm{g} / \mathrm{kg}\end{array}$ & 36 & 85 & 346 \\
\hline
\end{tabular}




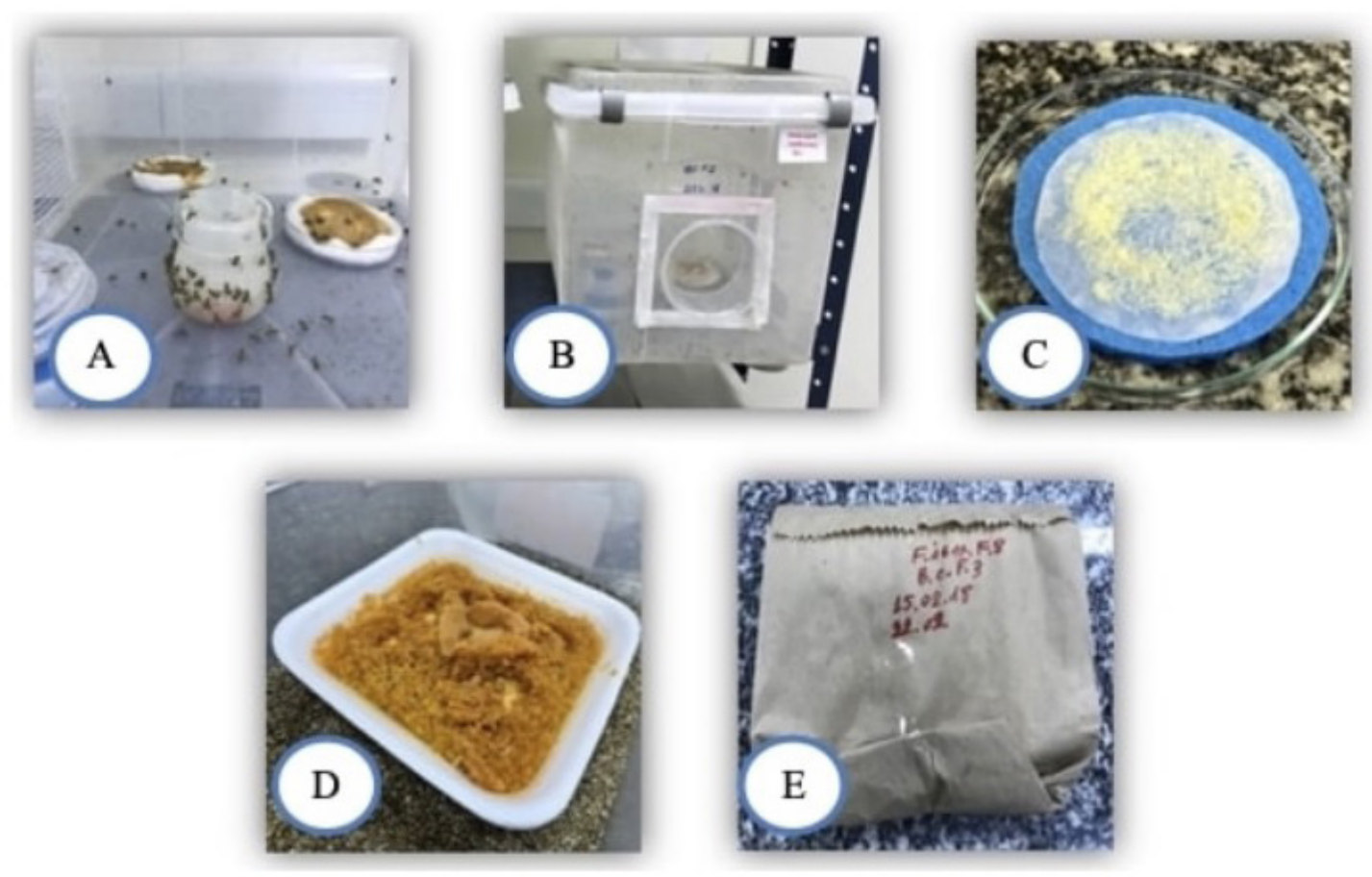

Figure 1 Representation of the steps for rearing B. carambolae: A) Oviposition container; B) Cage with adults; C) Eggs; D) Feed based on carrots in a plastic tray containing larvae; E) Paper envelope containing the plastic tray with larvae. Photos: Eric Joel Ferreira do Amaral.

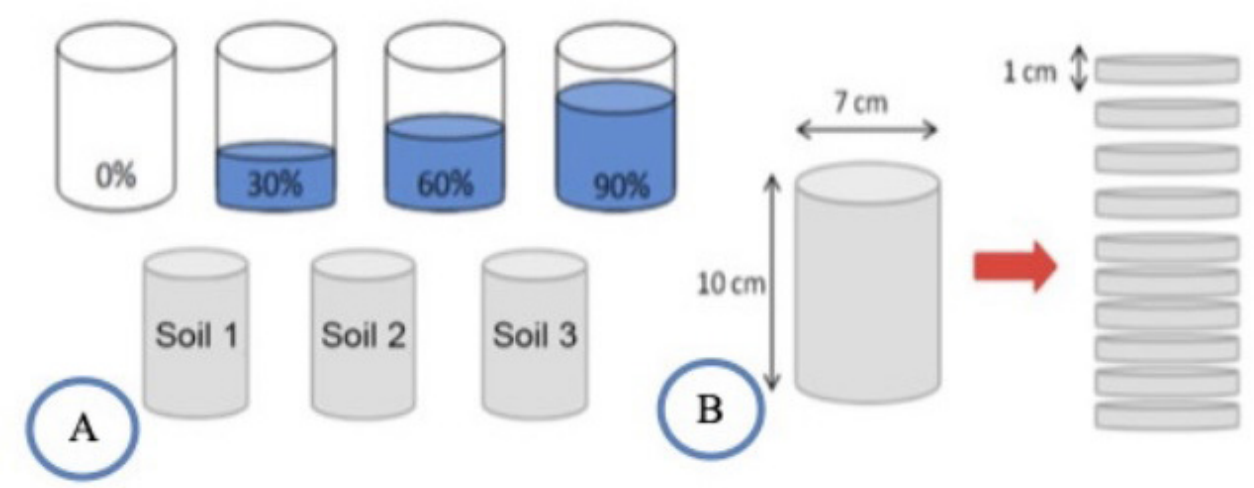

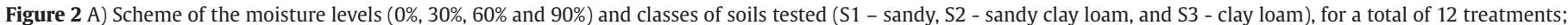
B) Polystyrene foam containers, divided into stacked $1 \mathrm{~cm}$ rings.

To determine the moisture levels used for each soil class in the experiment, we defined the field capacity according to the tube method, as described by Costa et al. (1997), which simulates the determination of this variable in pot conditions.

The containers were moistened until reaching the value corresponding to field capacity of each treatment. After two hours, the larvae were deposited on the soil surface (Fig. 3A). Then inverted plastic pots with the bottoms cut out and covered with organza cloth were placed on the top of the cylinders, held in place with rubber bands (Fig. 3B). The containers were inspected daily until the emergence of the flies, and the flies were counted until no further emergence was observed.

The pupation depth was measured 7 days after the start of emergence of the flies, by carefully removing the rings at each centimeter depth (Fig. 3C) and transferring the soil to a plastic tray (Fig. 3D). The content of each tray was sifted (Fig. 3E) for sorting and counting of the pupal cases at each $1 \mathrm{~cm}$ depth (Fig. $3 \mathrm{~F}$ ). Emerged adults that were unable to rupture the soil layer were counted separately.

\section{Data analysis}

Generalized linear models (GLMs) were used to test the effects of the soil type, moisture and depth on the number of pupae, as well as the effects of soil type and moisture on the number of adult flies emerged, using the pupation time (in days) as covariable. In this type of experiment there is no multicolinearity because for each soil type (sandy, sandy clay loam and clay loam) there are all treatments of moisture $(0 \%, 30 \%, 60 \%$ and $90 \%)$, depth $(0-10 \mathrm{~cm})$ and pupation time (1-7 days). The interactions of soil type with moisture and with depth were tested for pupae models and interactions of soil type with moisture and with time were tested for emergence models. We firstly used a poisson distribution to fit the data and calculated the ratio between residual deviance and residual degrees of freedom to test for overdispersion. As the ratios were higher than 1 (3.14 for pupae and 2.97 emergence models) we used a binomial negative distribution with a log link which includes a dispersion parameter. The analyses were performed with the R software, version 3.5.2 (R Core Team, 2018). 


\section{Results}

Of the 1,440 larvae used in the experiment, 1,286 pupae were obtained, from which 1,037 flies emerged, for a pupal emergence rate of $72 \%$. The emergence rates in each soil types were $84 \%$ for sandy, $72 \%$ for clay loam and $52 \%$ for sandy clay loam. Of the pupae recovered, $4 \%$ were on the soil surface, $23 \%$ were in the first centimeter, $44 \%$ in the second centimeter, $22 \%$ in the third, and $7 \%$ each in the fourth and fifth centimeters (Fig. 4).

Of the flies that emerged, $1.12 \%$ (12 flies) did not manage to rupture the soil layer. This occurrence was 6 flies in the clay loam soil and 6 flies in the sandy clay loam, both in the treatment with $0 \%$ moisture.

The number of pupae was slightly greater in the sandy soil (1.71 \pm 4.15 ; mean \pm standard deviation) than in the sandy clay loam
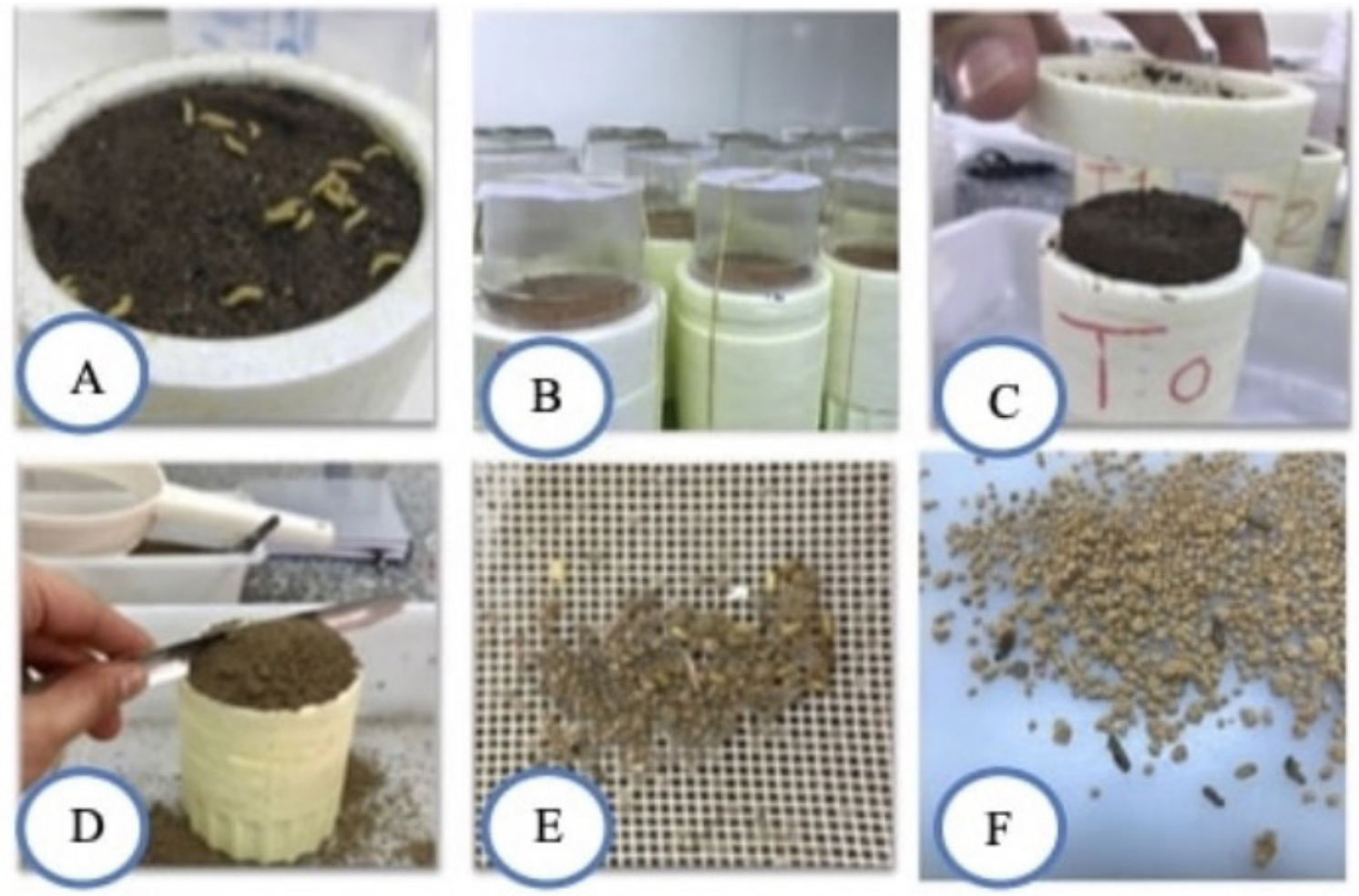

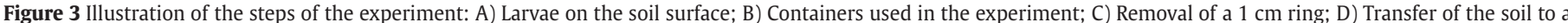
plastic tray; E) Sorting and counting of the pupal cases; and F) Insects that were unable to rupture the soil layer. Photos: Eric Joel Ferreira do Amaral.

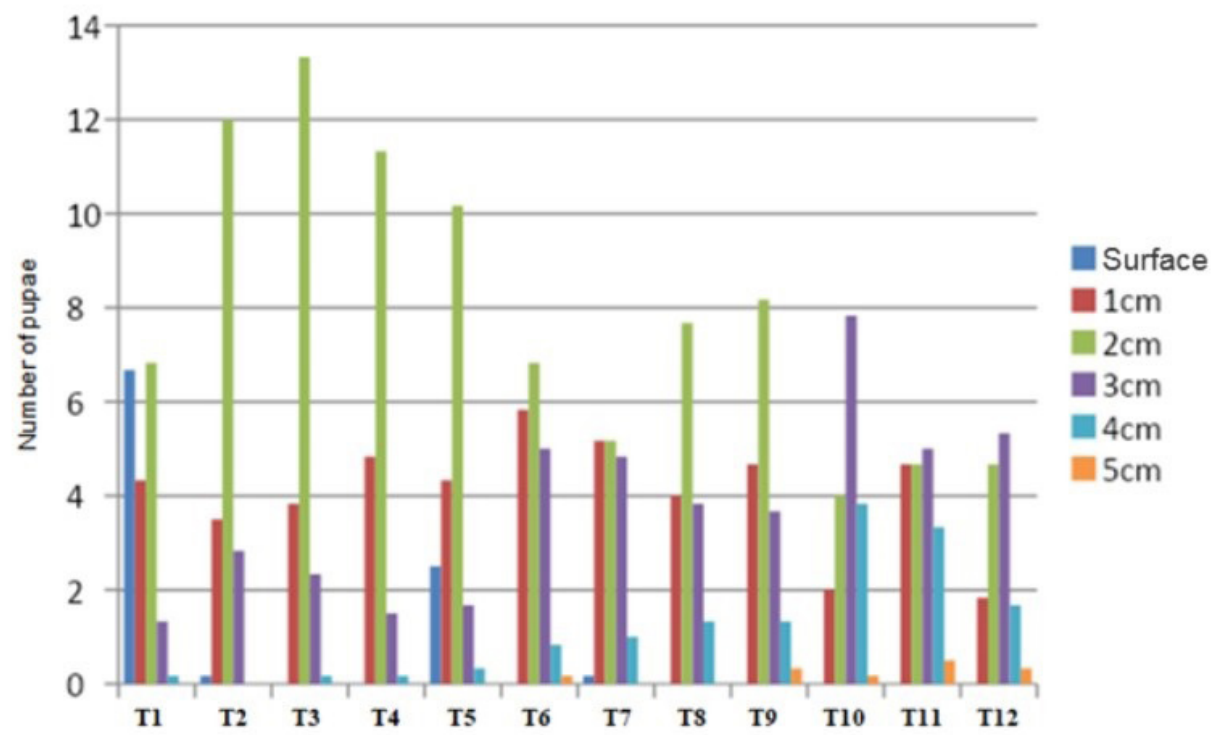

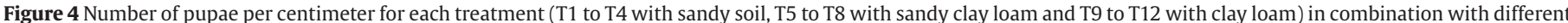

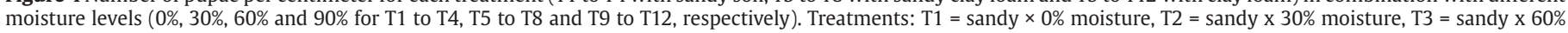

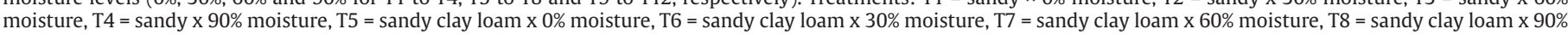

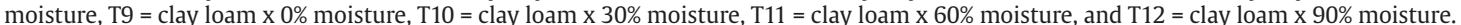


(1.61 \pm 2.99$)$ and clay loam soils $(1.55 \pm 2.82)$, but not statistically significant. Although the intercept (3.1 pupae) estimated with GLM for sandy soil was significantly different from zero (Wald-test: $z=10.22$, $\mathrm{df}=789, \mathrm{P}<0.001)$, the difference $(-0.27$ pupae) from sandy clay loam $(\mathrm{z}=-0.66, \mathrm{df}=789, \mathrm{P}=0.5)$ and the difference $(-0.47$ pupae) from clay loam soils $(\mathrm{z}=-1.16, \mathrm{df}=789, \mathrm{P}=0.25)$ were not significant. However, the pupation depth was dependent on the soil type (Fig. 5). In the sandy soil, the number of pupae diminished exponentially with increasing depth (GLM: $b=-0.98, z=-12.21, d f=785, P<0.001$ ), with absence of pupae at the depth of $5 \mathrm{~cm}$ (Fig. 5a). The effect was also strong for sandy clay loam ( $\mathrm{b}=-0.80, \mathrm{z}=1.73, \mathrm{df}=785, \mathrm{P}=0.08$ ) but more moderate for clay loam soils ( $b=-0.61, z=3.82$, $d f=785, P<0.001$ ), with one or zero pupa found starting at the depth of $6 \mathrm{~cm}$ (Figs. 5b and 5c). The moisture level did not have a significant effect on the pupation depth for any of the soil classes $(b=-0.001$ to $0.003, z=-0.63$ to $0.58, d f=785$, $\mathrm{P}>0.53$; Figs. $5 \mathrm{~d}$ and $5 \mathrm{f})$.

The number of adult insects that emerged was affected by the soil type, with the greatest number found in the sandy soil $(2.40 \pm 4.25$; mean \pm standard deviation), followed by clay loam $(2.05 \pm 3.08)$ and sandy clay loam ( $1.69 \pm 3.04)$. The intercept (3.99 emergents) estimated with GLM for sandy soil was significantly different from zero $(z=11.71$, $\mathrm{df}=501, \mathrm{P}<0.001)$ and higher than other soils since the differences from clay loam $(-1.65$ emergents, $\mathrm{Z}=-3.63, \mathrm{df}=501, \mathrm{P}<0.001)$ and from sandy clay loam soils $(-1.87$ emergents, $\mathrm{z}=-4.1, \mathrm{df}=501, \mathrm{P}<0.001)$ were highly significant.
The emergence of flies followed a nonlinear pattern, with peaks between the second and third day, and then diminished abruptly from the fourth day onward (Figs. $6 a$ and $6 c$ ). Besides this, the relation between the number of emerged flies and time presented different patterns depending on the soil type. The decline in the number of emerged flies with increasing pupation time was most pronounced in the sandy soil (GLM: $\mathrm{b}=-1.27, \mathrm{z}=-11.86, \mathrm{df}=499, \mathrm{P}<0.001$ ), where there was no emergence from the fifth day onward (Fig. $6 \mathrm{a}$ ). In the sandy clay loam $(b=-0.70, z=4.40, d f=499, P<0.001)$ and clay loam $(b=-0.74, z=4.03$, $\mathrm{df}=499, \mathrm{P}<0.001)$ the emergence declined less sharply and the flies continued emerging until the seventh day (Figs. $6 \mathrm{~b}$ and $6 \mathrm{c}$ ). The moisture level did not affect the fly emergence rate in any of the soil classes ( $b=0.006$ to $0.013, z=1.21$ a $1.40, d f=500, P>0.15$; Figs. $6 d$ and $6 f$ ).

\section{Discussion}

Of the pupae we recovered, $89 \%$ were at depths between 0 and $4 \mathrm{~cm}$, corroborating the results of Alyokhin et al. (2001), who observed that the majority of $B$. dorsalis larvae pupated in the first $4 \mathrm{~cm}$ layer. In our experiment, $10.7 \%$ of the larvae were not recovered. These possibly did not reach the pupal stage or dried out after pupating. Hodgson et al. (1998) performed field tests of the disappearance rate of Anastrepha Schiner pupae placed on the soil surface and at depths of 2.5 and $5 \mathrm{~cm}$, and monitored them daily for 10 days. The pupae on the surface
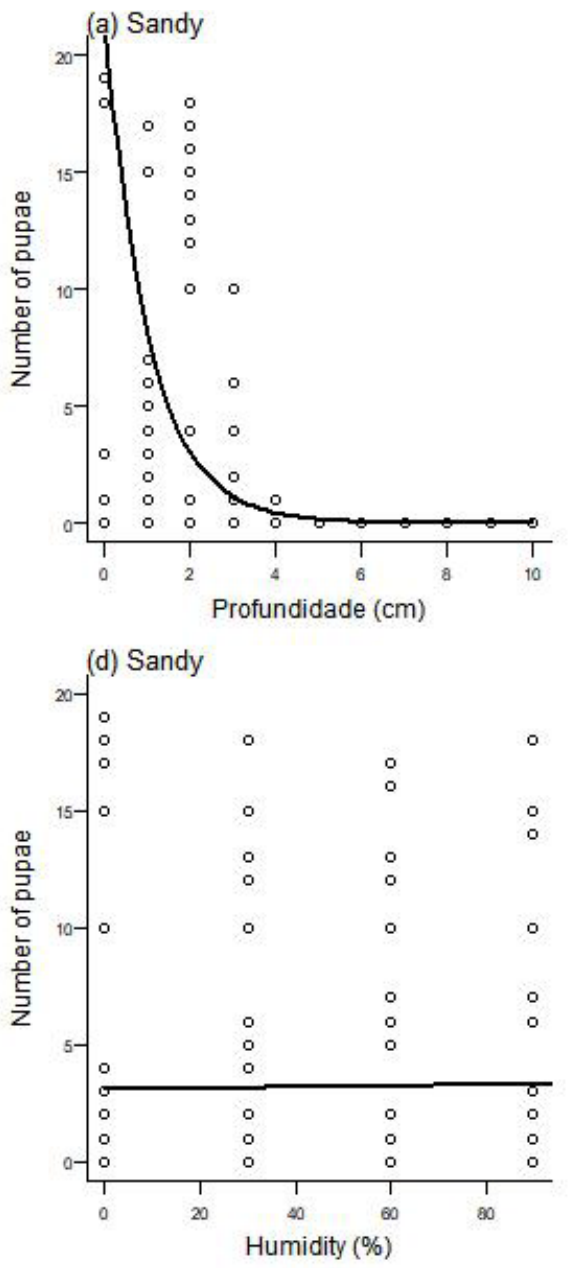

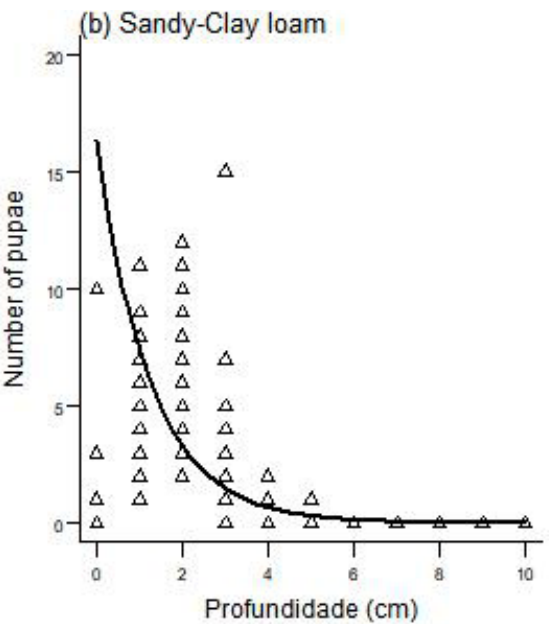

(e) Sandy-Clay loam

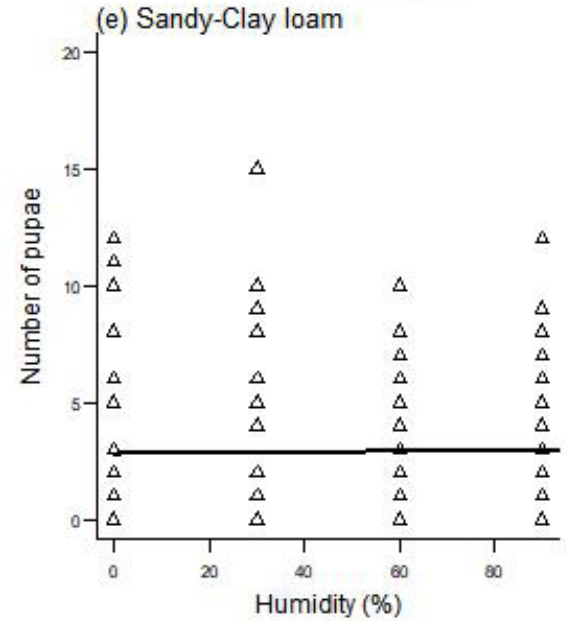

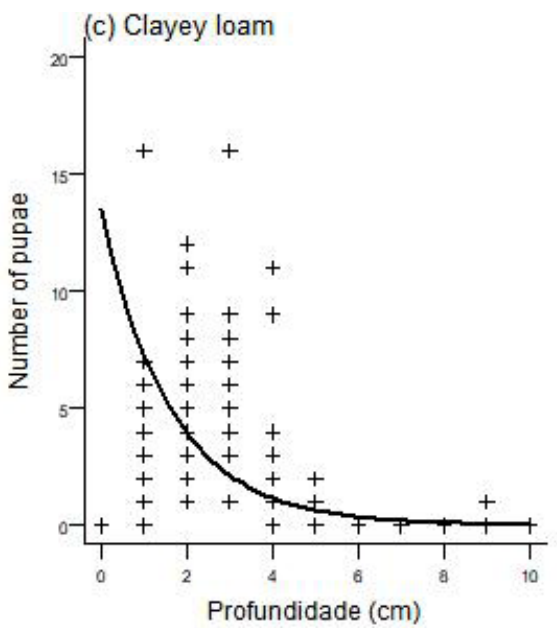

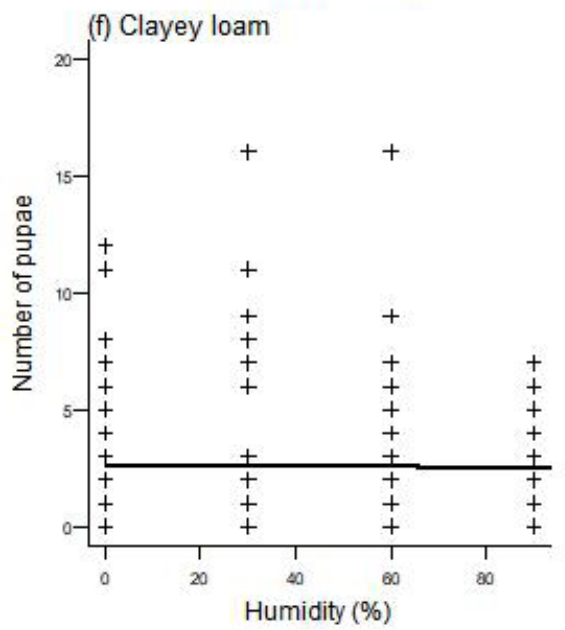

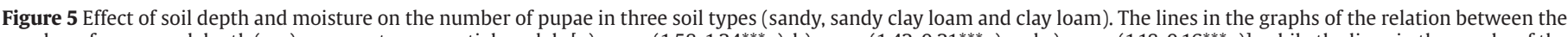

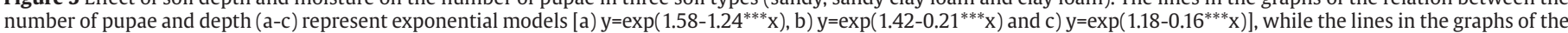

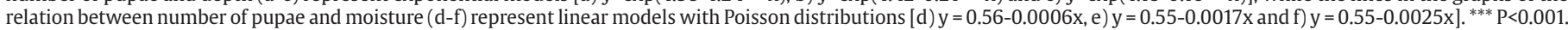



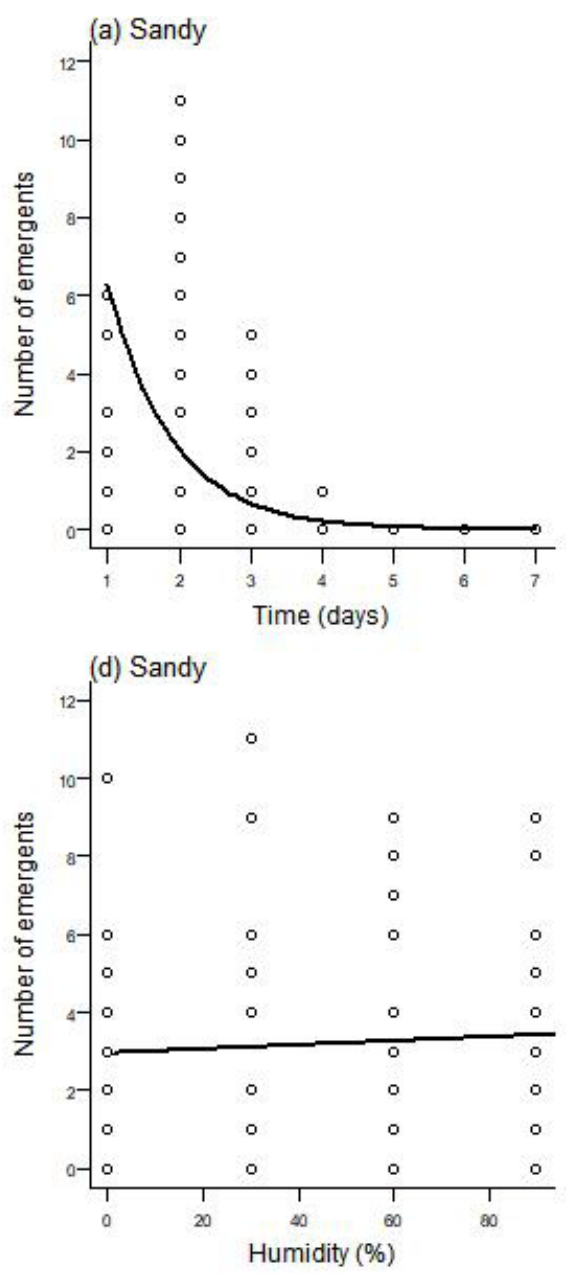
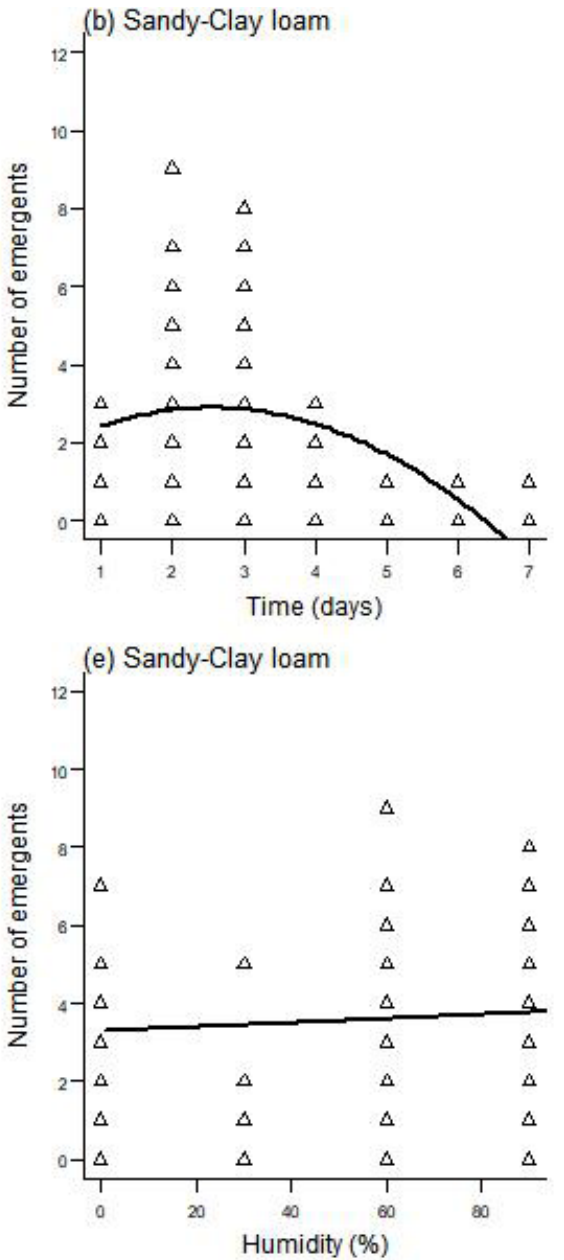
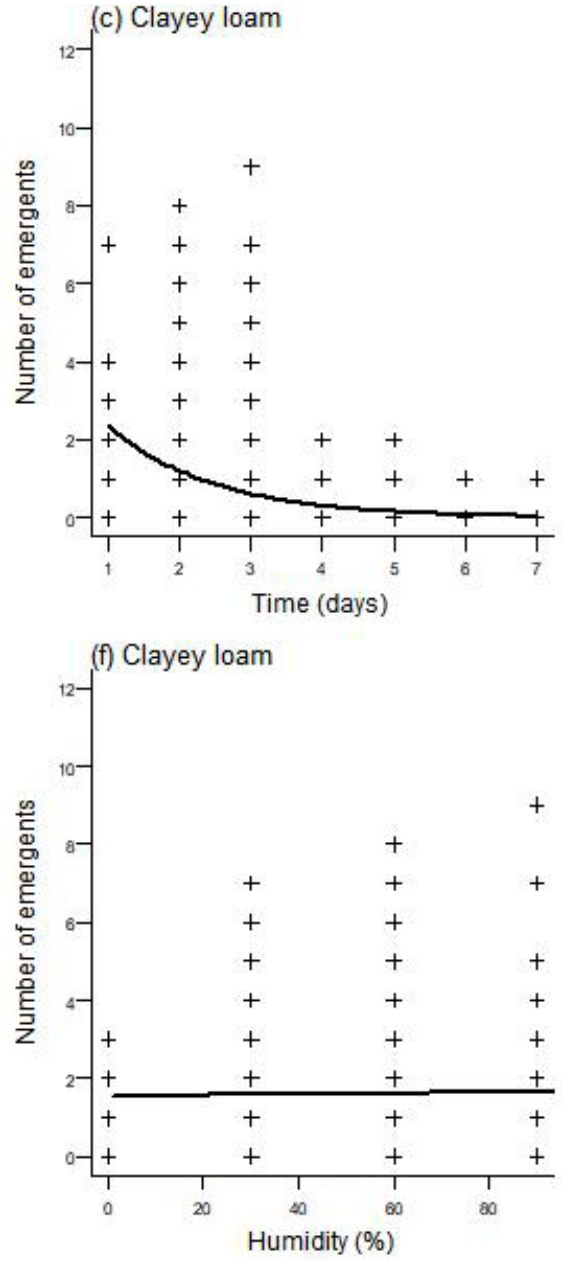

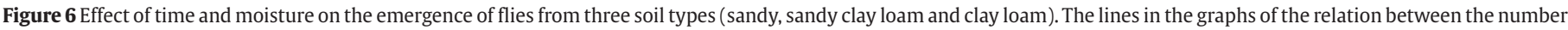

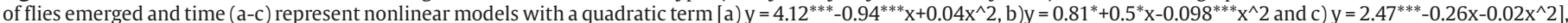

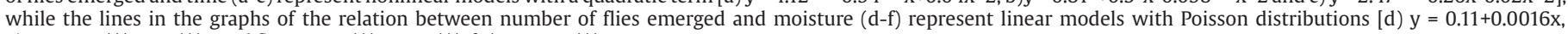
e) $y=-0.69^{* * *}+0.01^{* * *} x$ and f) $\left.y=-0.37^{* * *}+0.008^{* * *} x\right] .{ }^{*}: P<0.05 ;{ }^{* * *} P<0.001$.

invariably disappeared at a higher rate than those underground. There was no difference in the disappearance rate of the pupae buried at depths of 2.5 and $5 \mathrm{~cm}$, suggesting that larvae do not obtain benefits from burrowing to greater depths to pupate. In turn, Salles and Carvalho (1993) reported that larvae of Anastrepha fraterculus (Wiedemann) concentrated at depths from 0 to $10 \mathrm{~cm}$ in a natural setting, and when the soil compaction was greater, they only burrowed to a depth of $4 \mathrm{~cm}$.

The soil class was the most relevant factor influencing the pupal development of $B$. carambolae. In general, pupation decreased with the quantity of clay in the soil. There also was a negative effect of depth on pupation, since the number of pupae declined with increasing depth. This effect was influenced by the soil type, where soils with a greater concentration of sand (particle sizes ranging from $0.05 \mathrm{~mm}$ to $2 \mathrm{~mm}$ ) had a moderate negative effect on the number of pupae according to depth, while the soils with lower sand concentration presented a strong negative effect.

Hennessey (1994) observed that larvae of Anastrepha suspensa(Loew) pupated at greater depths in soils with low compaction and those with larger particle sizes, which generally have a structure with open pores, facilitating movement and penetration of the larvae to greater depths. The higher the percentage of small particles is, the greater the density and the less porous the soil will be, thus limiting the penetration of larvae and the exit of emerged flies. This hypothesis is supported by our observation of flies that were unable to leave the soil in the clay loam and sandy clay loam classes in the treatment with $0 \%$ moisture.

It is also important to note that low soil compaction not only favors pupation of fruit fly larvae at greater depths, it also facilitates the penetration of arthropod predators, with a negative impact on pupal mortality (Hodgson et al., 1998). However, this did not occur in our experiment since we did not allow the entry of predators. Salles and Carvalho (1993), investigating $A$. fraterculus, did not find a significant relationship of soil compaction with pupation time and number of insects emerged.

We observed a significant effect of the soil type on the emergence of $B$. carambolae, which declined with increasing concentration of clay in the soil. According to Milward-de-Azevedo and Parra (1989), the pupal viability of $C$. capitata is strongly affected in latosols, with observance of higher values under the driest conditions. In another soil tested, they reported that the highest viability rates occurred in soil samples with intermediate moisture levels.

Moisture alone was not significantly related with the pupation depth and emergence rate. However, its interaction with soil class had a significant effect, increasing the emergence with rising moisture in the clay loam and sandy clay loam soils, both having greater concentration of particles with small size. Dimou et al. (2003) tested the effects of moisture on pupation depth of Bactrocera spp. and found that in soils 
with moisture of $50 \%$ of field capacity individuals pupated at greater depths compared to soils with $10 \%$ of field capacity. In our experiment, we used a wider range of moisture levels. Bento et al. (2010) reported that the emergence of $C$. capitata was affected by moisture, irrespective of the soil type, and was greater in dry conditions. Salles et al. (1995), working with $A$. fraterculus, observed an interaction of moisture and temperature on the emergence of adults, with a stronger influence of temperature than moisture, but did not describe of the soil characteristics and moisture levels used in their experiment. They also demonstrated that extreme temperatures can impair pupal viability.

Jackson et al. (1998) reported evidence that fruit fly larvae pupated at a significantly greater depth in moist sand than in dry sand. They reported that excessive water loss was an important cause of mortality of pupae of $B$. dorsalis and $C$. capitata. This finding can be attributed to the variety of moisture levels utilized in the studies or to the pupation substrate, which varies not only in particle size but also compaction. Eskafi and Fernandez (1990) reported that C. capitata suffered greater mortality of larvae and pupae in dry soils with high density.

Our findings will facilitate prediction of the depth at which $B$. carambolae can pupate in the field according to the soil class and moisture level. Our results can also be useful to improve tests for biological control with entomopathogenic fungi $M$. anisopliae. In laboratory tests, the mortality of larvae and pupae of $B$. carambolae was $70 \%$. In addition, $100 \%$ of the adults who emerged died within five days after the emergency (Brito et al., 2019). Therefore, based on knowledge of the effects of different soil classes and moisture levels on the pupal development of $B$. carambolae, it will be possible to perform specific experiments under field conditions to try to maximize the performance of the fungus. For example, different levels of wetting can be tested that allow greater entomopathogen penetration in each soil class, ensuring better performance of the fungus on the pest.

\section{Acknowledgments}

To the National Council for Scientific and Technological Development (CNPq) for the Research Productivity Fellowship granted to Ricardo Adaime.

\section{Conflicts of interest}

The authors declare no conflict of interest.

\section{Author contribution statement}

EJFA, NJMJ, JJT and RA contributed to the concept and design of the study, data analysis and interpretation, and manuscript preparation. MSMS, JEVS and LMC contributed to data collection and critical reviews, adding intellectual content to the manuscript.

\section{References}

Adaime, R. A., Jesus-Barros, C. R., Bariani, A., Lima, A. L., Cruz, K. R., Carvalho, J. P., 2016. Novos registros de hospedeiros da mosca-dacarambola (Bactrocera carambolae) no Estado do Amapá, Brasil. Embrapa, Amapá. (Comunicado Técnico, 146).

Alyokhin, A. V., Mille, C., Messing, R. H., Duan, J. J., 2001. Selection of pupation habitats by oriental fruit fly larvae in the laboratory. J. Insect Behav. 14 (1), 57-67. http://dx.doi.org/10.1023/A:1007849629409.

Amaral, E. J. F., Bariani, A., Sousa, M. S. M., Silva, R. A., 2019. Técnica para estudo dos efeitos de classes texturais de solo e de níveis de umidade sobre a profundidade de pupação e viabilidade pupal de moscas-das-frutas. In: Pacheco, J.T.R., Kawanishi, J.Y., Nascimento, R. (Eds.), Meio ambiente e desenvolvimento sustentável 2. Editora Atena, Ponta Grossa, pp. 251-257. http://dx.doi.org/10.22533/ at.ed.55019111124.

Bariani, A., Jesus-Barros, C. R., Carvalho, J. P., Mota-Júnior, L. O., Nascimento, P. R., Cruz, K. R., Facundes, V. S., 2016. Técnicas para criação da mosca-da-carambola (Bactrocera carambolae Drew \& Hancock) em laboratório para pesquisa científica. Embrapa, Amapá. (Documento, 97).

Belo, A. P. D., Silva, L. M. S. E., Correa, J. M. G., Ferreira, R. M. A., Costa-Neto, S. V., Sousa, M. S. M., Adaime, R., Lemos, L. N., 2020. New host plants records of Bactrocera carambolae Drew \& Hancock and Anastrepha spp. (Diptera: Tephritidae) in Brazil. Entomological Communications 2, ec02036. http://dx.doi.org/10.37486/2675-1305.ec02036.

Bento, F. M., Marques, R. N., Costa, M. L. Z., Walder, J. M. M., Silva, A. P., Parra, J. R. P., 2010. Pupal development of Ceratitis capitata (Diptera: Tephritidae) and Diachasmimorpha longicaudata (Hymenoptera: Braconidae) at different moisture values in four soil types. Environ. Entomol. 39 (4), 1315-1322. PMid:22127183. http://dx.doi.org/10.1603/EN08088.

Brito, B. D., Lima, A. L., Cruz, K. R., Bariani, A., Jesus-Barros, C. R., Pereira, J. F., Adaime, R., 2019. Amazonian isolates of Metarhizium are effective for killing Bactrocera carambolae (Diptera: tephritidae). Acta Biol. Colomb. 24 (1), 118-124. http://dx.doi.org/10.15446/abc. v24n1.70275.

Buckman, H. O., Brady, N. C., 1974. Natureza e prioridades dos solos: compêndio universitário sobre edafologia. Freitas Bastos, Rio de Janeiro, 594 pp.

Castilho, A. P., Pasinato, J., Santos, J. E. V., Costa, A. S., Nava, D. E., Jesus, C. R., Adaime, R., 2019. Biology of Bactrocera carambolae (Diptera Tephritidae) on four hosts. Rev. Bras. Entomol. 63 (4), 302-307. http://dx.doi.org/10.1016/j.rbe.2019.09.002.

Costa, A. C. S., Nanni, M. R., Jeske, E., 1997. Determinação da umidade na capacidade de campo e ponto de murchamento permanente por diferentes metodologias. Rev Unimar. 19 (3), 827-844.

Dimou, I., Koutsikopoulos, C., Economopoulos, A. P., Lykakis, J., 2003. Depth of pupation of the wild olive fruit fly, Bactrocera (Dacus) oleae (Gmel.) (Diptera, Tephritidae), as affected by soil abiotic factors. J. Appl. Entomol. 127 (1), 12-17. http://dx.doi.org/10.1046/j.14390418.2003.00686.x.

Eskafi, F. M., Fernandez, A., 1990. Larval-pupal mortality of mediterranean fruit fly (Diptera: Tephritidae) from interaction of soil, moisture, and temperature. Environ. Entomol. 19 (6), 1666-1670. http://dx.doi. org/10.1093/ee/19.6.1666.

Godoy, M. J. S., Pacheco, W. S., Portal, R. R., Pires-Filho, J. M., Moraes, L. M., 2011. Programa Nacional de Erradicação da mosca-da-carambola. In: Silva, R.A., Lemos, W.P., Zucchi, R.A. (Eds.), Moscas-das-frutas na Amazônia Brasileira: diversidade, hospedeiros e inimigos naturais. Vol. 1. Embrapa, Amapá, pp. 135-172.

Hennessey, M. K., 1994. Depth of pupation of caribean fruit fly (Diptera: Tephritidae) in soils in the laboratory. Environ. Entomol. 23 (5), 1119-1123. http://dx.doi.org/10.1093/ee/23.5.1119.

Hodgson, P. J., Sivinski, J., Quintero, G., Aluja, M., 1998. Depth of pupation and survival of fruit fly (Anastrepha spp.: Tephritidae) pupae in a range of agricultural habitats. Environ. Entomol. 27 (6), 1310-1314. http://dx.doi.org/10.1093/ee/27.6.1310.

Hulthen, A. D., Clarke, A. R., 2006. The influence of soil type and moisture on pupal survival of Bactrocera tryoni(Froggatt) (Diptera: tephritidae). Aust. J. Entomol. 45 (1), 16-19. http://dx.doi.org/10.1111/j.14406055.2006.00518.x.

Jackson, C. G., Long, J. P., Klungness, L. M., 1998. Depth of pupation in four species of fruit flies (Diptera: Tephritidae) in sand with and 
without moisture. J. Econ. Entomol. 91 (1), 138-142. http://dx.doi. org/10.1093/jee/91.1.138.

Malavasi, A. 2015. Mosca-da-carambola, Bactrocera carambolae Drew \& Hancock. In: Vilela, E. F., Zucchi, R. A. (Eds.), Pragas introduzidas no Brasil, insetos e ácaros. FEALQ São Paulo, pp. 173-184.

Malavasi, A., Zucchi, R. A., 2000. Moscas-das-frutas de importância econômica no Brasil: conhecimento básico e aplicado. Holos, São Paulo, 325 pp.

Milward-de-Azevedo, E. M. V., Parra, J. R. P., 1989. Influência da umidade em dois tipos de solo, na emergência de Ceratitis capitata. Pesqui. Agropecu. Bras. 24 (3), 321-327.

Ministério da Agricultura, Pecuária e Abastecimento - MAPA, 2018. Resolução ${ }^{\circ}$ 6, de 23 de nov. de 2018. Diário Oficial da União, Brasília.

Miranda, S. H. G., Nascimento, A. M., Ximenes, V. P., 2015. Potenciais impactos socioeconômicos da expansão da mosca-da-carambola. In: Vilela, E.F., Zucchi, R.A. (Eds.), Pragas introduzidas no Brasil: insetos e ácaros. FEALQ, São Paulo, pp. 132-149.

Moniz, A. C., 1975. Elementos de pedologia. Livros Técnicos e Científicos, Rio de Janeiro, 459 pp.

Nikiforoff, C. C., 1941. Morphological classification of soil structure. Soil Sci. 52 (3), 193-212. http://dx.doi.org/10.1097/00010694194109000-00003.
R Core Team 2018. R: a language and environment for statistical computing. R Foundation for Statistical Computing, Austria. Available in: https://www.R-project.org/ (accessed 07 August 2020).

Salles, L. A. B., Carvalho, F. L. C., 1993. Profundidade da localização da pupária de Anastrepha fraterculus (Wied.) (Diptera: Tephritidae) em diferentes condições do solo. An. Soc. Entomol. Bras. 22 (2), 299-305.

Salles, L. A. B., Carvalho, F. L. C., Raiser Junior, C., 1995. Efeito da temperatura e umidade do solo sobre pupas e emergência de Anastrepha fraterculus (Wied.). An. Soc. Entomol. Bras. 24 (1), 147-152.

Silva, T. L., Lima, A. L., Sousa, M. S. M., Jesus-Barros, C. R., Bariani, A., Pereira, J. F., Adaime, R., 2016. Potential of Amazonian isolates of Metarhizium to control immatures of Bactrocera carambolae (Diptera: tephritidae). Fla. Entomol. 99 (4), 788-789. http://dx.doi. org/10.1653/024.099.0436.

Teixeira, P. C., Donagemma, G. K., Fontana, A., Teixeira, W. G., 2017. Manual de métodos de análise de solo. Rio de Janeiro, Embrapa. 573 pp.

Veihmeyer, F. J., Hendrickson, A. H., 1931. The moisture equivalent as a measure of the field capacity of soils. Soil Sci. 32 (3), 181-194. http://dx.doi.org/10.1097/00010694-193109000-00003.

Veihmeyer, F. J., Hendrickson, A. H., 1949. Methods of measuring field capacity and permanent wilting percentage of soils. Soil Sci. 68 (1), 75-94. http://dx.doi.org/10.1097/00010694-194907000-00007. 